\title{
Amplification and Overexpression of Elongin C Gene Discovered in Prostate Cancer by cDNA Microarrays
}

\author{
Kati Porkka, Outi Saramäki, Minna Tanner, and Tapio Visakorpi \\ Laboratory of Cancer Genetics, Institute of Medical Technology, University of Tampere and Tampere University \\ Hospital, Tampere, Finland
}

\begin{abstract}
SUMMARY: Functional significance of several oncogenes is mediated by overexpression. To identify overexpressed genes in prostate cancer, we analyzed expression of 1081 transcripts in three prostate cancer cell lines (PC-3, DU145, and LNCaP) using CDNA microarray hybridization. The cDNA microarray analyses were validated by quantitative real-time RT-PCR. On average, $64 \%$ of the genes were expressed at detectable levels in the cell lines. Next, the expression profiles were combined with the data on DNA sequence copy number alterations in the cell lines obtained by comparative genomic hybridization. The genes for Elongin $\mathrm{C}$ and urokinase type plasminogen-activator, both located in the regions of amplification in the PC-3 cell line (8q21 and 10q22, respectively), were found to be overexpressed in the PC-3. Amplification and overexpression of urokinase type plasminogenactivator in prostate cancer has previously been reported. Here, fluorescence in situ hybridization on tissue microarray showed high-level amplification of the Elongin C gene in 8 (23\%) of 35 hormone-refractory carcinomas but in none of the untreated prostate carcinomas $(n=35)$. Finally, it was shown that the Elongin $C$ gene was overexpressed and amplified also in breast cancer cell line SK-Br-3. The results indicate that Elongin C is a putative target gene for $8 \mathrm{q}$ amplification. (Lab Invest 2002,
\end{abstract} 82:629-637).

$D$ uring the last several years, a major emphasis in the field of prostate cancer research has been in identification of the genes involved in the development and progression of the disease, using strategies such as positional cloning (Elo and Visakorpi, 2001). In positional cloning, the chromosomal locus harboring the disease gene is first identified, eg, by classical cytogenetic, loss of heterozygosity, comparative genomic hybridization (CGH), or linkage analyses. Subsequently, the genes in the region of interest are individually studied to identify the actual target gene of the genetic aberration (Collins, 1995; Forozan et al, 1997). Although the screening of chromosomal aberrations is relatively rapid and easy with the currently available techniques, the recognition of the true target gene for the aberration is still tedious and difficult. For example, $\mathrm{CGH}$ and loss of heterozygosity analyses have already revealed the most commonly altered chromosomal regions in prostate cancer, but many of the target genes for these aberrations are not known (Elo and Visakorpi, 2001).

An alternative approach to find genes involved in the development of cancer is to identify differentially expressed genes. There are several techniques for screening such genes, eg, subtraction hybridization

Received February 4, 2002.

Supported by grants from the Academy of Finland, Cancer Society of Finland, Reino Lahtikari Foundation, the Medical Research Fund of Tampere University Hospital, Sigrid Juselius Foundation, and by a contract with the Finnish Life and Pension Insurance companies.

Address reprint requests to: Dr. Tapio Visakorpi, Laboratory of Cancer Genetics, Institute of Medical Technology, FIN-33014, University of Tampere, Finland.E-mail: tapio.visakorpi@uta.fi
(Hedrick et al, 1984), differential display (Liang and Pardee, 1992), representational difference analysis (Hubank and Schatz, 1994; Lisitsyn et al, 1993), and serial analysis of gene expression (Velculescu et al, 1995). Maybe the most exciting of these new techniques is, however, cDNA microarray hybridization (Schena et al, 1995). With cDNA microarrays expression of thousands of genes can be studied simultaneously. It has already been used for both identification of novel prostate cancer-related genes and classification of prostate tumors based on their expression profiles (Dhanasekaran et al, 2001; Magee et al, 2001; Welsh et al, 2001; Xu et al, 2000).

Because many chromosomal alterations affect gene expression, combining analysis of expression and chromosomal aberrations may be useful in efforts to clone cancer-causing genes. This is especially true for amplified oncogenes, because amplification of a chromosomal region is believed to lead to the overexpression of the true target gene for the amplification (Anzick et al, 1997; Collins et al,1998; Monni et al, 2001; Nupponen et al, 1999, 2000). Here, our goal was first to identify overexpressed genes in three prostate cancer cell lines (PC-3, DU145, and LNCaP) by cDNA microarray hybridization and then to find out which of the overexpressed genes were likely to be amplified by combining the expression data with $\mathrm{CGH}$ findings. We found that genes for Elongin $C$ and urokinase-type plasminogen activator (UPA) were overexpressed in the PC-3 cell line that contained amplification of the chromosomal regions harboring the genes 8q21 and 10q22, respectively. The overexpression of UPA and Elongin $\mathrm{C}$ was verified by quantitative RT-PCR techniques (LightCycler, Roche Diagnostics, Mannheim, 
Table 1. The Primer and Probe Sequences Used in the Real-Time RT-PCR

\begin{tabular}{cll}
\hline Gene & \multicolumn{1}{c}{ Primer sequences $\left(5^{\prime}-3^{\prime}\right)$} & \multicolumn{1}{c}{ Hybridization probe sequences $\left(5^{\prime}-3^{\prime}\right)$} \\
\hline Elongin C & ACCTATGGTGGCTGTGAAGG & \\
& AGGTGCAATTGGGATTCAG & \\
uPA & TCACCACCAAAATGCTGTGT & TCCCCCTGAGTCTCCCTGGCA-Fluorescein \\
& AGGCCATTCTCTTCCTTGGT & Red640-AATCTGTTTCCACTGTGGGTCAGCAG \\
TOP2A & GATTCTAGTTAATGCTGCGGAC & CACAAAGTTGAAAAGATGTATGTCCCA-Fluorescein \\
& AGACTTTGACATCTTTGGTGGA & Red640-LC CTCTCATATTTGGACAGCTCCTAACTTC \\
TBP & GAATATAATCCCAAGCGGTTGG & TTTCCCAGAACTGAAAATCAGTGCC-Fluorescein \\
& ACTTCACATCACAGCTCCCC & Red640-TGGTTCGTGGCTCTCTTATCCTCATG \\
\hline
\end{tabular}

uPA, urokinase-type plasminogen activator; TOP2A, topoisomerase II alpha; TBP, TATA-box binding protein.

Germany). Next, the frequency of Elongin C amplification in prostate cancer was studied by using fluorescence in situ hybridization (FISH) and the tissue microarray technique. Finally, we analyzed the gene copy number and expression of the Elongin $\mathrm{C}$ gene in cell lines derived from malignant and nonmalignant epithelial cells of the mammary gland.

\section{Results}

\section{cDNA Microarray Hybridization}

Of the 1081 genes, 660 (61\%), 564 (52\%), and 846 (78\%) showed signal intensities over the background in PC-3, DU145, and LNCaP cell lines, respectively. Table 2 lists the 10 most highly overexpressed genes in the 3 cell lines. The genes can be functionally categorized into the following groups: cell cycle regulators (CDK1, CDK5, CCNB1, and CCNA), ribosomal proteins (RPS21 and RPS3A), DNA polymerases and replication-associated proteins (topoisomerase II alpha [TOP2A] and RPA3), proteases (UPA and CAPN2), nuclear receptors/transcription factors (orphan hormone nuclear receptor and MYC), apoptosis/cell proliferation-associated proteins (CAS and API4), and miscellaneous (NDKA, HSP90A, Elongin C, caveolin 2, calmodulin, KIAA0175, PSMA, and GIRK2).

Next, we compared the expression levels with chromosomal alterations in the cell lines that we have previously found by CGH (Nupponen et al,1998a). The chromosomal localization of the analyzed 1081 genes was

Table 2. Ten Most Overexpressed Genes in Each Cell Line

\begin{tabular}{|c|c|c|c|c|c|c|}
\hline I & 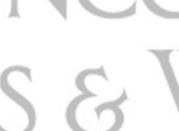 & & & & $\begin{array}{l}\text { ative expr } \\
\text { ording to } \\
\text { microarr }\end{array}$ & $\begin{array}{l}\text { ssion } \\
\text { cDNA } \\
\text { y }\end{array}$ \\
\hline Gene & Abbreviation & number & Locus & PC-3 & DU145 & LNCaP \\
\hline Cell division cycle 2 & CDC2 & X05360 & $10 q 21$ & $8.3^{a}$ & 3.7 & 9.3 \\
\hline Urokinase type plasminogen activator & UPA & M15476 & $10 \mathrm{~g} 22$ & 7.1 & 1.6 & $-^{b}$ \\
\hline Orphan hormone nuclear receptor & & Z30425 & $x$ & 7.1 & - & - \\
\hline Cellular apoptosis susceptibility protein & CAS & U33286 & $20 \mathrm{~g} 13$ & 7.0 & 2.8 & 2.0 \\
\hline Nucleoside diphosphate kinase A & NDPKA & $\mathrm{X} 17620$ & $17 q 21$ & 6.9 & 1.0 & 6.4 \\
\hline Topoisomerase II alpha & TOP2A & J04088 & $17 q 21-22$ & 6.6 & 11.2 & 4.1 \\
\hline 90-kd heat shock protein A & HSP9OA & X07270 & $?$ & 5.7 & 1.2 & 4.1 \\
\hline Elongin $\mathrm{C}$, transcription elongation factor $\mathrm{B} 1$ & TCEB1 & L34587 & $8 q 21$ & 5.5 & 1.0 & 2.1 \\
\hline Ribosomal protein S21 & RPS21 & L04483 & $20 \mathrm{q} 13$ & 5.3 & 1.3 & 7.7 \\
\hline Cyclin B1 & CCNB1 & M25753 & $5 q 12$ & 5.2 & 8.2 & 13.6 \\
\hline Apoptosis inhibitor 4 & API4 & U75285 & $17 q 25$ & 4.3 & 4.5 & 2.6 \\
\hline Caveolin 2 & CAV2 & AF035752 & $7 q 31$ & - & 3.7 & 3.7 \\
\hline Calmodulin 2 & CALM2 & D45887 & $2 \mathrm{p} 21$ & 1.6 & 3.6 & 1.2 \\
\hline Calpain 2 & CAPN2 & M23254 & $1 q 41-42$ & 3.4 & 3.2 & - \\
\hline KIAA0175 & & D79997 & 9p12 & 2.7 & 3.1 & 3.1 \\
\hline Replication protein A3 & RPA3 & L07493 & $7 \mathrm{p} 22$ & 3.8 & 2.9 & 2.6 \\
\hline Prostate-specific membrane antigen & PSMA & M99487 & $11 \mathrm{p} 11$ & 0.9 & - & 9.0 \\
\hline Cyclin-dependent kinase 5 & CDK5 & $\mathrm{X} 66364$ & $7 \mathrm{q} 36$ & - & - & 7.5 \\
\hline Ribosomal protein 3a & RPS3A & M77234 & $4 q 31$ & 0.6 & 1.2 & 6.5 \\
\hline c-myc & MYC & V00568 & $8 q 24$ & 2.9 & 1.1 & 5.6 \\
\hline G-protein activated inward rectifier potassium channel 2 & GIRK2 & U24660 & $21 \mathrm{q} 22$ & 2.3 & - & 5.7 \\
\hline Cyclin $2 \mathrm{~A}$ & CCNA & X51688 & $4 \mathrm{q} 25-31$ & - & - & 5.7 \\
\hline
\end{tabular}

${ }^{a}$ The 10 most highly expressed genes in each cell line are marked in bold

${ }^{b}$ Expression below the detection limit. 
retrieved from public databases (http://www.ncbi.nlm. nih.gov/LocusLink/ and http://www.ensembl.org/). The relative expression value of each gene, obtained by cDNA microarrays, was plotted against the distance $(\mathrm{Mb})$ of the gene from pter of each chromosome (Fig. 1). The resulting expression profiles were compared with the CGH profiles. The cell lines contain only a few high-level amplifications according to $\mathrm{CGH}$ analysis. PC-3 contains amplifications of 8q13-qter, 10p12-q23, and $14 q 21-q 24$. DU145 contains gain of $14 q$ including amplification at 14cen-q21, whereas LNCaP does not have any amplifications according to $\mathrm{CGH}$ analysis (Nupponen et al, 1998a). By combining the CGH and gene expression data, we identified two genes that were located in a region of amplification and were consistently overexpressed in the cell line containing the amplification. These were genes for UPA at 10q22 and for Elongin $\mathrm{C}$ (TCEB1) at 8q21. uPA was expressed more than four times higher in PC-3 than in DU145 and more than seven

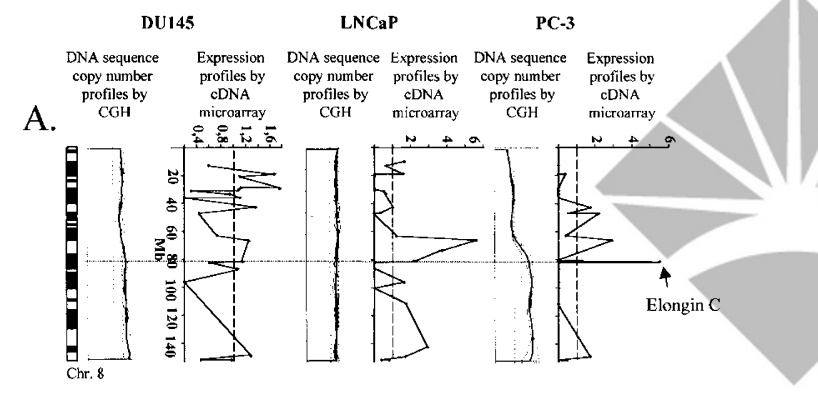

B.

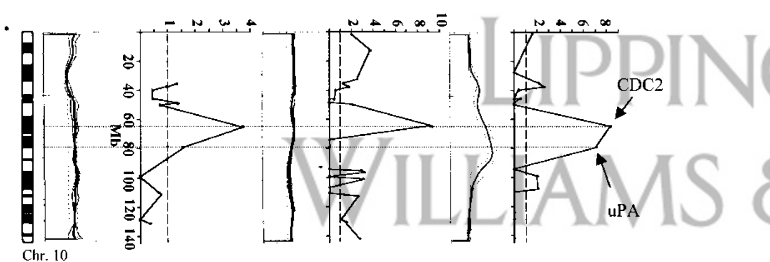

C.

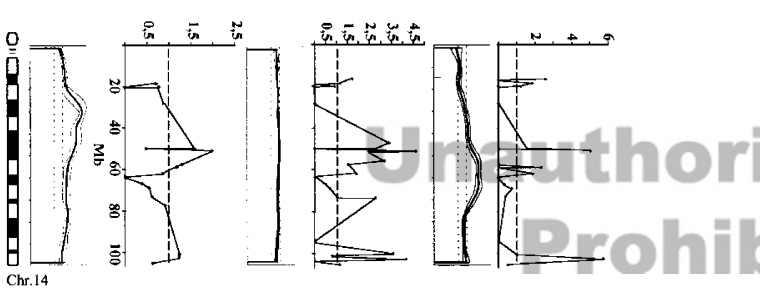

times higher in PC-3 than in LNCaP. Elongin C was overexpressed more than five times higher in PC-3 than in DU145 and more than two times higher in PC-3 than in LNCaP.

\section{Confirmation of Differential Expression by RT-PCR}

To verify the cDNA microarray findings, the expression of UPA, Elongin $\mathrm{C}$, and TOP2A was measured by quantitative RT-PCR. Figure 2 shows a standard curve of the real-time RT-PCR measurement of Elongin C. The linear standard curve ranged from 0.16 to 250 of total RNA. The relative value of expression (as compared with the expression of TATA-box binding protein [TBP]) of Elongin $C$ was 27.6, 5.4, and 2.4 in the PC-3, DU145, and LNCaP cell lines, respectively. The relative value of expression of UPA was 151.5, 53.8, and 0 in the PC-3, DU145, and LNCaP cell lines, respectively. The relative value of expression of TOP2A was 9.3, 18.0, and 4.5 in the PC-3, DU145, and $\mathrm{LNCaP}$ cell lines, respectively. The cDNA microarray hybridization and quantitative RT-PCR gave similar differences in the expression levels of the three genes in the three cell lines (Fig. 2).

\section{FISH}

To verify the chromosomal localization of the Elongin $C$ gene, we first mapped the gene using the genespecific BAC probe and FISH. The gene mapped to $8 q 21$ (Fig. 3A). Next, the copy number of the gene was analyzed in the three cell lines. The PC-3 cell line contains 6 to 12 copies of the gene and 2 to 4 copies of chromosome 8 centromere (ratio 3) (Fig. 3B), whereas DU145 contains only 3 and LNCaP only 4 copies of the gene and centromere (ratio $~ 1)$. To evaluate the frequency of Elongin $\mathrm{C}$ amplification in prostate cancer, we screened 35 untreated and 35 locally recurrent hormone-refractory prostate tumors for copy number alterations. Of the untreated specimens, 12 (34\%) showed low-level gain of the gene, and none showed high-level amplification. Eight (23\%) of the 35 hormone-refractory tumors showed amplification, and $19(54 \%)$ showed low-level gain of the gene (Fig. 3C).

Figure 1.

CDNA microarray analysis of expression and comparative genomic hybridization (CGH) analysis of chromosomal alterations of chromosome $8(\mathrm{~A}), 10(\mathrm{~B})$, and $14(C)$ in the three prostate cancer cell lines. Previously published (Nupponen et al, 1998a) mean cancer to normal ratio of the fluorescence intensities with \pm 1 SD from pter to qter obtained are shown. The dotted vertical lines in the CGH profiles represent ratio values of 0.85 and 1.15. CGH analysis of the DU145 cell line indicates low-level gain of $8 q$ and $14 q$ together with an amplification at 14cen-q21. The PC-3 cell line shows an amplification of $8 q, 10 p 12-q 23$, and $14 q 21-q 24$. LNCaP has no alterations on these chromosomes by $\mathrm{CGH}$. Relative expression values for the genes located in these chromosomes are shown in the three cell lines. The distance $(\mathrm{Mb})$ of the genes from the pter of the chromosomes was retrieved from public databases. The dotted horizontal lines in $A$ and $B$ indicate Elongin $C$, cell division cycle 2 (CDC2), and urokinase type plasminogen-activator (UPA) genes. Elongin $C$ and UPA are overexpressed and located in the region of amplification only in the PC-3 cell line. CDC2 is highly expressed in all three cell lines but located in the region of amplification in only $\mathrm{PC}-3$. In chromosome 14, there was no gene that was overexpressed and consistently located in the regions of amplification.

\section{Analyses of Breast Cancer Cell Lines}

Of the breast cancer cell lines T47D, MDA426, SKBr-3, MDA415, ZR75-1, MCF-7, and EFM19, and MCF10A originated from fibrocystic disease of the mammary gland, only SK-Br-3 showed amplification of Elongin $\mathrm{C}$ as evidenced by, on average, 12 Elongin $\mathrm{C}$ and 1 centromere 8 signals (ratio $\sim 12$ ). The quantitative RT-PCR analysis of the cell lines indicated that Elongin- $C$ was expressed about four times more in the SK-Br-3 line compared with the other breast cell lines (Fig. 2F).

\section{Discussion}

Development of cancer is associated with differential expression of many genes, some of which are genet- 
A.

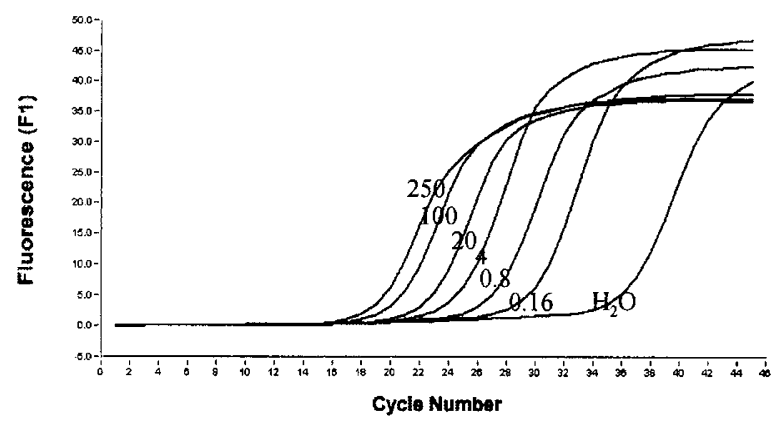

C.

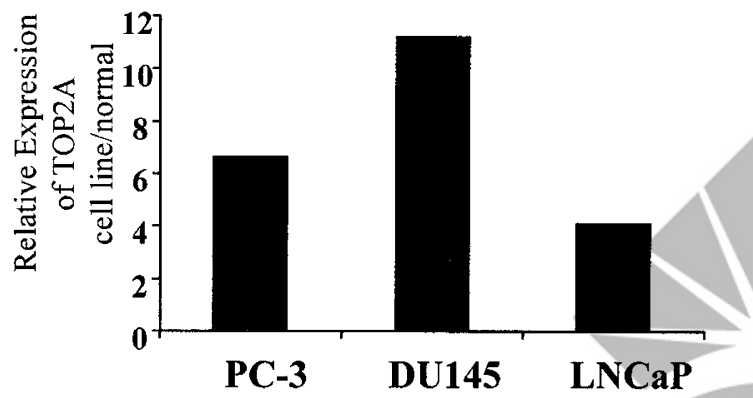

B.

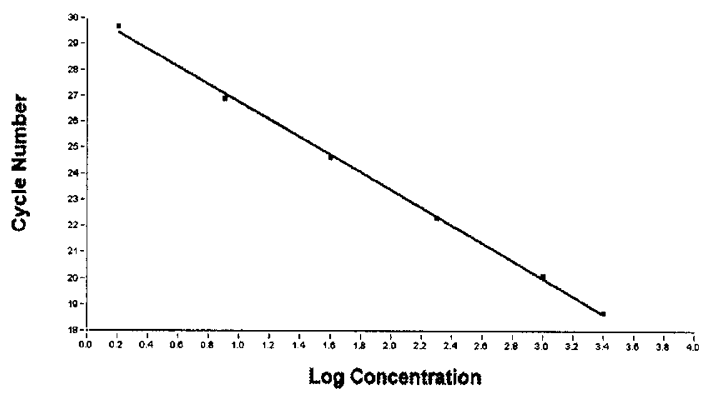

D.

E.

F. prostate cancer

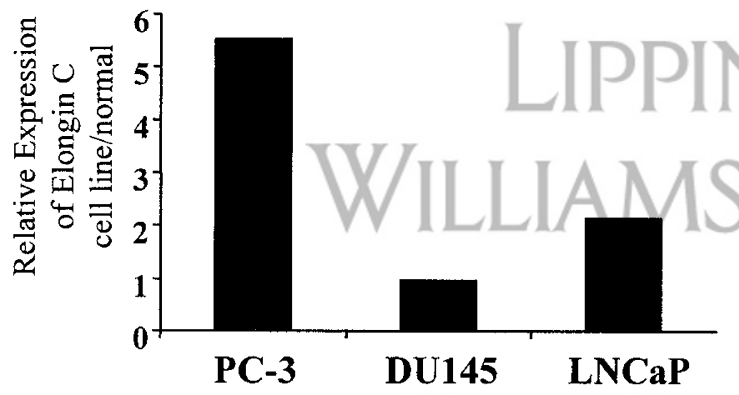

G.

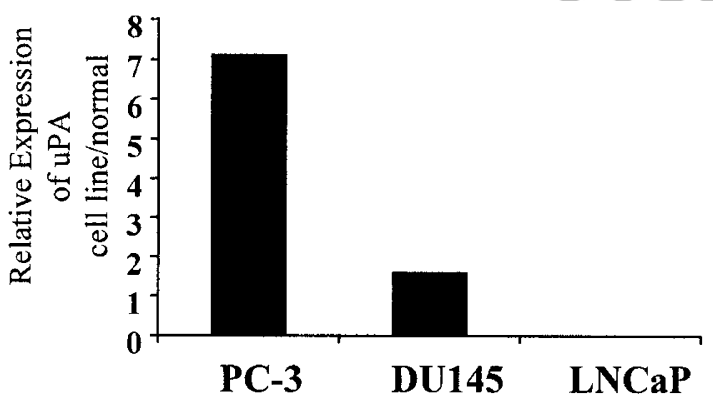

H.

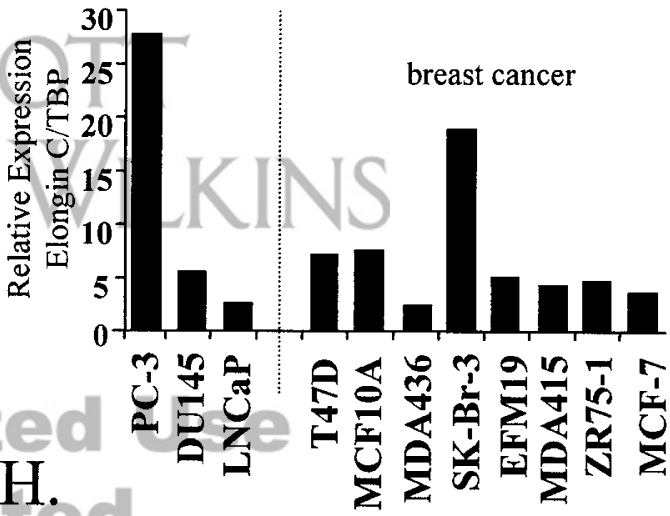

Figure 2.

A, Serially diluted standards containing CDNA transcribed from 250, 100, 20, 4, 0.8, and $0.16 \mathrm{ng}$ of total RNA measured by real-time RT-PCR with Elongin C-specific primers. Also, the negative control $\left(\mathrm{H}_{2} \mathrm{O}\right)$ gives signal in late cycles because of formation of primer-dimers. B, Standard curve for Elongin $\mathrm{C}$ plotting fractional cycle number at the fluorescent threshold for each standard curve presented in A. C. The relative expression value (cell line versus normal) of the topoisomerase II alpha (TOP2A) gene according to CDNA microarray hybridization. D, The relative expression value (TOP2A versus TBP) of the TOP2A gene according to real-time RT-PCR. $E$ and $F$, The relative expression value of the Elongin $C$ gene according to $C D N A$ microarray hybridization (E) and real-time RT-PCR (F). $G$ and $H$, The relative expression value of the uPA gene according to cDNA microarray hybridization $(\mathrm{G})$ and real-time RT-PCR $(\mathrm{H})$. 

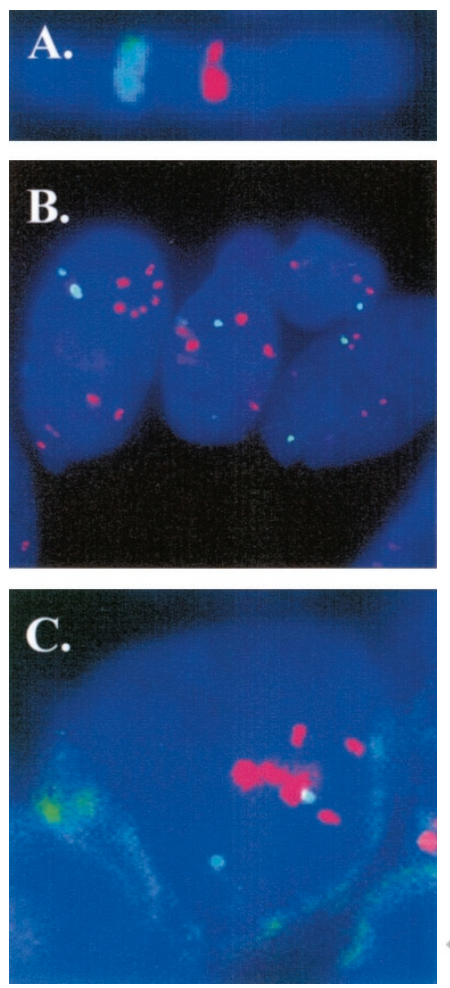

Figure 3.

Two-color fluorescence in situ hybridization (FISH) analyses of Elongin C (red) and chromosome 8 centromere (green). A, Elongin $\mathrm{C}$ maps to normal chromosome 8q21. B, interphase nuclei of PC-3 cell lines show two copies of chromosome 8 centromere and $\sim 6$ copies of Elongin C, indicating 3-fold amplification of the gene. C, An example of hormone-refractory tumor with six to nine copies of Elongin $C$ and two copies of the chromosome 8 centromere. The chromosomes and nuclei were counterstained with 4,6-diamidino 2-phenylindole (blue).

ically altered. For example, amplification of an oncogene is believed to lead to the overexpression of the gene (Alitalo and Schwab, 1986). Thus, detection of consistent overexpression of an amplified gene has been used to recognize the true target gene of amplification (Anzick et al, 1997; Collins et al,1998; Monni et al, 2001; Nupponen et al, 1999, 2000). Here, we used cDNA microarray hybridization to detect overexpression of more than a thousand genes in three prostate cancer cell lines.

To validate the detection of expression by cDNA microarray, we also analyzed the expression of three genes (UPA, Elongin C, and TOP2A) in the cell lines by quantitative RT-PCR. For example, according to microarray, the highest expression of TOP2A was in DU145, followed by PC-3 and LNCaP. Exactly the same order and about the same differences between the cell lines were found using quantitative RT-PCR. The Elongin $\mathrm{C}$ gene, which was found to be highly expressed only in PC-3 by microarray analysis, was expressed more than 5 times higher in PC-3 than in DU145 and more than 10 times higher in PC-3 than in LNCaP, according to quantitative RT-PCR. Finally, the cDNA microarray and RT-PCR results on expression of UPA were in good agreement. These three examples clearly indicate the usefulness of the microarray methodology in detection of overexpressed genes.
Because cDNA microarray hybridization was made using mRNA from normal prostate gland as a reference, it was not surprising that many of the overexpressed genes in the cell lines were cell cycle-associated genes (CDK1, CDK5, CCNB1, CCNA, TOP2A, RPA3 CAS, and API4). Based purely on the expression levels, it is difficult to evaluate the significance of overexpression of any of these genes in prostate cancer. Therefore, we compared the expression profiles with the DNA sequence copy profiles of the cell lines. The goal was to find genes that were overexpressed in the cell lines that showed amplification of the chromosomal regions harboring the particular genes. When expression of the genes and CGH data of cell lines were compared, two genes, UPA and Elongin C, showed the most consistent overexpression together with amplification of the chromosomal region mapping the genes.

The expression of the urokinase (UPA) gene was four to seven times higher in PC-3 than in LNCaP and DU145, respectively, according to cDNA microarray hybridization, and it localized to the region of amplification in PC-3 according to $\mathrm{CGH}$. We and others (Helenius et al, 2001; Hollas et al, 1992) have previously shown that the PC-3 cell line contains 20 to 30 copies of the UPA gene and that it is expressed more than twice as much in PC-3 than DU145 as measured by Northern analysis. The lack of or very low-level of expression of UPA in LNCaP, found here by both cDNA microarray and RT-PCR, is also in concordance with the previous findings by Northern analyses (Helenius et al, 2001; Hollas et al, 1992). We have earlier demonstrated the significance of uPA gene amplification by showing that the PC-3 cell line is more sensitive to inhibition of UPA than DU145 and LNCaP as evaluated by Matrigel invasion assay (Helenius et al, 2001). In addition, we have shown that the uPA gene is amplified in about $10 \%$ of hormone-refractory prostate carcinomas, further indicating that uPA may be involved in the progression of prostate cancer (Helenius et al, 2001).

The overexpression of Elongin $\mathrm{C}$ found in PC-3 was especially interesting because the gene is located in $8 q 21$. The gain of $8 q$ is one of the most common chromosomal alterations in late-stage prostate cancer. By $\mathrm{CGH}$, it is found in about $70 \%$ to $90 \%$ of hormone-refractory or metastatic prostate carcinomas, and it seems to be associated with poor prognosis (Alers et al, 2000; Cher et al, 1996; Nupponen et al, 1998b). We and others have previously mapped the minimal commonly amplified regions to two separate chromosomal fragments, 8q21 and 8q23-q24 (Cher et al, 1996; Nupponen et al, 1998b). The 8q23-q24 region contains several putative target genes for the amplification, such as c-myc, ElF3S3, GC79, and PSCA (Chang et al, 2000; Jenkins et al, 1997; Nupponen et al, 1999; Reiter et al, 1998). However, much less in known about the 8q21 amplicon. According to quantitative RT-PCR, the Elongin $\mathrm{C}$ was expressed more than 5 times higher in PC-3 than in DU145 and more than 10 times higher in PC-3 than in LNCaP. PC-3 showed 6 to 12 copies of the Elongin $C$ gene by 
FISH, whereas DU145 and LNCaP showed only 3 and 4 copies of the gene, respectively. The copy number data is consistent with spectral karyotyping analysis, which has shown that PC-3 contains both hypotriploid and hypopentaploid clones containing several rearrangements involving fragments of chromosome 8 (Pan et al, 2001). We also analyzed prostate tumors for Elongin $\mathrm{C}$ amplification. About one-fifth of the hormone-refractory tumors showed an amplification of the gene. The frequency is slightly lower than, for example, the frequency of an amplification of EIF3S3 $(\sim 30 \%)$ located at the other minimal region of amplification, at 8q23 (Saramäki et al, 2001). None of the untreated tumors showed an amplification of Elongin $\mathrm{C}$, suggesting that the amplification is associated with the late progression of prostate cancer. The finding is consistent with the earlier CGH studies indicating that $8 \mathrm{q}$ gain is a late event in the development of prostate cancer (Visakorpi et al, 1995).

Because gain of $8 q$ is one of the most common gains also in breast cancer (Tirkkonen et al 1998), we decided to analyze breast cancer cell lines for the Elongin $\mathrm{C}$ gene copy number and expression. Of the cell lines, only SK-Br-3 showed high-level amplification of the gene. It also had the highest expression level of the gene. According to CGH, SK-Br-3 contains high-level amplification of the two minimal regions of the 8q gain, 8q21 and 8q23-q24 (Kallioniemi et al, 1992). Therefore, we have previously used this cell line, for example, as a primary model for $8 q$ gain (Nupponen et al,1999, 2000). The findings on the breast cancer cell lines support the possibility that Elongin $C$ is a target gene for the amplification of $8 q 21$ region.

Elongin C (alias TCEB1) is a subunit of the elongin (SIII) complex, which activates elongation of transcription by RNA polymerase II. The complex is a heterotrimer composed of $A, B$, and $C$ subunits of 110,18 , and $15 \mathrm{kd}$, respectively (Bradsher et al, 1993; Garrett et al, 1994). Elongin $A$ is the transcriptionally active component of the complex, whereas Elongin $B$ and $C$ are the regulatory subunits. The RNA polymerase II has a tendency to pause at several positions downstream of the transcription initiation site. The binding of Elongin $A$ to the $B / C$ complex results in a relief of the pausing and a high transcript level (Aso et al, 1995; Krumm and Groudine, 1995). The suggestion that Elongin $\mathrm{C}$ could be involved in tumorigenesis comes from studies showing that Elongin $\mathrm{B}$ and $\mathrm{C}$ bind to $\mathrm{a}$ protein product of the von Hippel-Lindau tumor suppressor (VHL) gene (Duan et al, 1995; Kibel et al, 1995; Krumm and Groudine, 1995). Germline mutations in VHL predispose to multiple forms of cancer, especially to renal carcinomas. In addition, the majority of sporadic clear cell renal carcinomas contain mutations in the VHL gene (Linehan and Klausner, 1997). VHL mutations are frequently located in the region that binds to Elongin B and C gene (Duan et al, 1995; Kibel et al, 1995). Early works suggested that VHL negatively regulates the transcriptional elongation by binding to Elongin $C$ and thus preventing the formation of the Elongin $\mathrm{A} / \mathrm{B} / \mathrm{C}$ complex. It was shown that, in patients with defective VHL, the Elongin $\mathrm{A} / \mathrm{B} / \mathrm{C}$ complex accumulates, leading to increased level of transcription (Duan et al, 1995; Kibel et al, 1995; Krumm and Groudine, 1995). However, it has recently been suggested that mutations in VHL cause cancer by preventing ubiquitination of hypoxia-inducible factor alpha (HIF1 $\alpha$ ) leading to overexpression of $\operatorname{HIF} 1 \alpha$. Accumulation of the HIF1 $\alpha$ transcription factor then leads to excessive expression of the target genes of HIF1, such as vascular endothelial growth factor (Kondo and Kaelin, 2001). Therefore, Elongin C might be involved in the tumorigenesis through either regulation of transcription elongation or regulation of destruction of HIF1 $\alpha$. So far, no VHL mutations have been reported in prostate cancer. Thus, the finding of amplification and overexpression of Elongin $\mathrm{C}$, which counteracts the VHL, is very intriguing. To our knowledge, this is a first time that genetic alteration (amplification) of Elongin $\mathrm{C}$ has been reported in cancer.

In conclusion, cDNA microarray analysis proved to be useful in identification of overexpressed genes in prostate cancer. By combining data from the microarray and $\mathrm{CGH}$ analysis, we found that Elongin $\mathrm{C}$ gene is amplified and overexpressed in the PC-3 prostate cancer cell line. FISH analysis showed that about one-fifth of the hormone-refractory prostate tumors contain Elongin $\mathrm{C}$ amplification. These findings suggest that Elongin $C$ may well be one of the target genes for amplification of 8q21.

\section{Materials and Methods \\ Cell Lines and Tissue Material}

Prostate cancer cell lines PC-3, LNCaP, and DU145; breast/cancer cell lines T47D, MDA426, SK-Br-3, MDA415, ZR75-1, and MCF-7; and MCF10A originating from fibrocystic disease of mammary gland were obtained from American Type Culture Collection (Rockville, Maryland). EFM19 was purchased from DSMZ GmbH (Brauschweig, Germany). The cell lines were cultured under recommended conditions. Thirtyfive formalin-fixed paraffin-embedded untreated prostate cancer specimens from prostatectomies and 35 locally recurrent hormone-refractory prostate carcinomas from transurethral resection operations were obtained from Tampere University Hospital. A tissue microarray block was made from the original formalinfixed paraffin-embedded tumor blocks according to published guidelines (Kononen et al, 1998). A routine hematoxylin-eosin-stained slide was used to evaluate the representativeness of the samples.

\section{cDNA Microarray Hybridization}

Total RNA was extracted from subconfluent cell lines using TRIzol reagent (Life Technologies, Grand Island, New York), and poly $(A)^{+}$RNA was isolated from the total RNA by using Qiagen's Oligotex resin (Qiagen $\mathrm{GmbH}$, Germany). Human normal prostate poly $(\mathrm{A})^{+}$, which was used as a reference in each hybridization, was purchased from Clontech Laboratories Inc. (Palo 
Alto, California). Cy3- and Cy5-labeled cDNA probes were synthesized from two micrograms of poly $(A)^{+}$ RNA using a Micromax Direct cDNA Microarray system (NEN Life Science Products, Inc., Boston, Massachusetts) except for the cDNA synthesis primers, which were replaced by CDS Primer Mix (Clontech Laboratories Inc.). After the synthesis, combined Cy3 and Cy5 probes were purified and concentrated by using Microcon YM-30 columns (Millipore Corporation, Bedford, Massachusetts). The probe mix was then added to GlassHyb Hybridization Solution (Clontech Laboratories Inc) and denatured at $90^{\circ} \mathrm{C}$ for 2 minutes and hybridized to Atlas Glass Human 1.0 Microarray slides (Clontech Laboratories Inc.) under coverslips. The hybridization was performed in a moist chamber at $50^{\circ} \mathrm{C}$ for 16 hours, after which the slides were washed with GlassHyb Wash Solution, $1 \times$ SSC, and $0.1 \times$ SSC according to the Atlas Glass Microarrays User Manual (Clontech Laboratories Inc.). The list of the 1081 genes on the Atlas Glass 1.0 Array slide is available through the manufacturer's website (http://www.clontech.com/atlas/genelists/index.shtml).

The fluorescence intensities of Сy 3 and Cy 5 were measured by using a ScanArray 4000 laser confocal scanner (GSI Lumonics, Billerica, Massachusetts). The local background of each spot was subtracted. Next, the upper $95 \%$ confidence interval of average signal intensities of the negative controls (8 spots of $\lambda$ DNA and 24 spots of buffer) was calculated and subtracted from the signal values of the rest of the spots. The slides contained eight spots of housekeeping genes. The mean signal value of the housekeeping genes was used for normalization (the ratio of mean expression of housekeeping genes in a cell line and reference equals 1 ).

\section{RT-PCR}

Total RNA from the subconfluent cell lines was extracted using TRIzol reagent (Life Technologies) and was used for the first-strand CDNA synthesis with Superscript II reverse transcriptase and oligo $\mathrm{d}(\mathrm{T})_{12-18}$ primer according to the manufacturer's protocol (Life Technologies). For preparing the standard curve, $5 \mu \mathrm{g}$ of total RNA of normal prostate (Clontech Laboratories Inc.) was reverse transcribed. After the first-strand cDNA synthesis, serial dilutions were made to correspond to cDNA transcribed from 250, 100, 20, 4, 0.8, and $0.16 \mathrm{ng}$ of total RNA. Primers and probes for Elongin C, urokinase (UPA), TOP2A, and TBP genes are given in Table 1. To avoid amplification of any genomic DNA, the forward and reverse primers for each gene were chosen from different exons.

The PCR reactions were performed in the LightCycler apparatus (Wittwer et al, 1997) using either the LC-FastStart DNA Master SYBR Green I Kit (for Elongin C) or the LC-FastStart DNA Hybridization Probes Kit (for uPA, TOP2A, and TBP) (Roche Diagnostics, Mannheim, Germany). Thermocycling for the analysis of TBP and UPA genes was performed as previously described (Helenius et al, 2001; Linja et al, 2001). For Elongin $\mathrm{C}$, the reaction was performed in a final volume of $20 \mu \mathrm{l}$ containing $2 \mu \mathrm{l}$ of cDNA sample (or standard), $4 \mathrm{~mm} \mathrm{MgCl}, 0.5 \mu \mathrm{M}$ of each primer, as well as $1 \times$ ready-to-use reaction mix including Taq DNA polymerase, reaction buffer, dNTP mix, and SYBR Green dye. After 10 minutes of initial denaturation at $95^{\circ} \mathrm{C}$, the cycling conditions of 45 cycles consisted of denaturation at $95^{\circ} \mathrm{C}$ for 15 seconds, annealing at $59^{\circ} \mathrm{C}$ for 5 seconds, and elongation at $72^{\circ} \mathrm{C}$ for 11 seconds. The PCR cycles were followed by melting curve analysis according to the manufacturer's protocol (Roche Diagnostics). The LightCycler apparatus measured the fluorescence (SYBR Green) of each sample in every cycle at the end of the elongation step. For TOP2A, the reactions were performed in a final volume of $20 \mu \mathrm{l}$ containing $2 \mu \mathrm{l}$ of cDNA sample (or standard), $4 \mathrm{~mm} \mathrm{MgCl}, 0.5 \mu \mathrm{M}$ of each primer, 0.2 $\mu \mathrm{M}$ of fluorescein, and $0.4 \mu \mathrm{M}$ LC Red640-labeled probes as well as $1 \times$ ready-to-use reaction mix including Taq DNA polymerase, reaction buffer, and dNTP mix. After 10 minutes of initial denaturation at $95^{\circ} \mathrm{C}$, the cycling conditions of 55 cycles consisted of denaturation at $95 \mathrm{C}^{\circ}$ for 10 seconds, annealing at $56 \mathrm{C}^{\circ}$ for 10 seconds, and elongation at $72 \mathrm{C}^{\circ}$ for 25 seconds. The LightCycler apparatus measured the fluorescence of each sample in every cycle at the end of the annealing step. After background adjustment, the software produced the standard curve by measuring the crossing point of each standard and plotting the points against the logarithmic values of concentrations. The expression levels of Elongin C, uPA, and TOP2A were normalized by the housekeeping gene TBP as earlier described (Linja et al, 2001). After the PCR, every sample was also run in an agarose gel electrophoresis to ensure the amplified product was the correct size. In addition, the melting curve analysis was used to ensure the purity of the amplified PCR product of Elongin C.

\section{FISH}

A human genomic $\mathrm{BAC}$ clone containing the Elongin $\mathrm{C}$ (RP11-367E12) gene was obtained from Research Genetics (Huntsville, Alabama). The authenticity of the clone was verified by PCR with Elongin C-specific primers (forward 5'-acc tat ggt ggc tgt gaa gg-3', and reverse $5^{\prime}$-agg tgc aat tgg gaa ttc ag-3'). The FISH analysis on metaphase preparations from normal lymphocytes and the cancer cell lines was performed as previously described (Nupponen et al, 2000). For the analysis of prostate tumors, a 5- $\mu \mathrm{m}$ section from the tissue microarray block was cut onto a SuperFrost Plus slide (Menzel-Gläser, Braunschweig, Germany) and used for FISH analysis as essentially described earlier (Saramäki et al, 2001). Briefly, a locus-specific $\mathrm{BAC}$ probe and a pericentromeric probe for chromosome 8 (pJM128) were labeled by nick translation with digoxigenin and fluorescein-isothiocyanate, respectively. The deparaffinized slides were pretreated with 1 M NaSCN for 10 minutes at $80^{\circ} \mathrm{C}$, followed by incubation in $4 \mathrm{mg} / \mathrm{ml}$ pepsin (Sigma P-7012 [St. Louis, Missouri], in $0.9 \% \mathrm{NaCl}, \mathrm{pH} 1.5)$ for 5 minutes at $37^{\circ} \mathrm{C}$. After hybridization for 2 to 3 days at $37^{\circ} \mathrm{C}$, the 
slides were washed, and the locus-specific probes were detected immunohistochemically by antidigoxigenin rhodamine. The slides were counterstained with $0.1 \mathrm{M}$ 4,6-diamidino 2-phenylindole in Vectashield antifade solution (Vector Laboratories Inc., Burlingame, California).

The FISH signals were scored from nonoverlapping epithelial cells using an Olympus BX50 epifluorescence microscope (Tokyo, Japan). A Photometrics CCD camera (Photometrics, Tuscon, Arizona) and IPLab software program (Scananalytics Inc., Fairfax, Virginia) were used to capture images. The tumors were classified into three groups: normal (two copies of the gene and centromere signals per cell), low-level gain (three to four copies per cell), and high-level amplification (five or more copies of the genes per cell or signal clusters).

\section{References}

Alers JC, Rochat J, Krijtenburg PJ, Hop WC, Kranse R, Rosenberg C, Tanke HJ, Schroder FH, and van Dekken $\mathrm{H}$ (2000). Identification of genetic markers for prostatic cancer progression. Lab Invest 80:931-942.

Alitalo K and Schwab M (1986). Oncogene amplification in tumor cells. Adv Cancer Res 47:235-281.

Anzick SL, Kononen J, Walker RL, Azorsa DO, Tanner MM, Guan XY, Sauter G, Kallioniemi OP, Trent JM, and Meltzer PS (1997). AIB1, a steroid receptor coactivator amplified in breast and ovarian cancer. Science 277:965-968.

Aso T, Lane WS, Conaway JW, and Conaway RC (1995). Elongin (SIII): A multisubunit regulator of elongation by RNA polymerase II. Science 269:1439-1443.

Bradsher JN, Jackson KW, Conaway RC, and Conaway JW (1993). RNA polymerase II transcription factor SIII. I. Identification, purification, and properties. J Biol Chem 268:2558725593.

Chang GT, Steenbeek M, Schippers E, Blok LJ, van Weerden WM, van Alewijk DC, Eussen BH, van Steenbrugge GJ, and Brinkmann AO (2000). Characterization of a zinc-finger protein and its association with apoptosis in prostate cancer cells. J Natl Cancer Inst 92:1414-1421

Cher ML, Bova GS, Moore DH, Small EJ, Carroll PR, Pin SS, Epstein JI, Isaacs WB, and Jensen RH (1996). Genetic alterations in untreated metastases and androgenindependent prostate cancer detected by comparative genomic hybridization and allelotyping. Cancer Res 56:30913102.

Collins FC (1995). Positional cloning moves from peritoneal to traditional. Nat Genet 9:347-350.

Collins C, Rommens JM, Kowbel D, Godfrey T, Tanner M, Hwang S, Polikoff D, Nonet G, Cochran J, Myambo K, Jay KE, Froula J, Cloutier T, Kuo W-L, Yaswen P, Dairkee S, Giovanola J, Hutchinson GB, Isola J, Kallioniemi O-P, Palazzolo M, Martin C, Ericsson C, Pinkel D, Albertson D, Li W-B, and Gray JW (1998). Positional cloning of ZNF217 and NABC1: Genes amplified at 20q13.2 and overexpressed in breast carcinoma. Proc Natl Acad Sci USA 95:8703-8708.

Dhanasekaran SM, Barrette TR, Ghosh D, Shah R, Varambally S, Kurachi K, Pienta KJ, Rubin MA, and Chinnaiyan AM (2001). Delineation of prognostic biomarkers in prostate cancer. Nature 412:822-826.
Duan DR, Pause A, Burgess WH, Aso T, Chen DY, Garrett KP, Conaway RC, Conaway JW, Linehan WM, and Klausner RD (1995). Inhibition of transcription elongation by the VHL tumor suppressor protein. Science 269:1402-1406.

Elo JP and Visakorpi T (2001). Molecular genetics of prostate cancer. Ann Med 33:130-141.

Forozan F, Karhu R, Kononen J, Kallioniemi A, and Kallioniemi OP (1997). Genomic screening by comparative genomic hybridization. Trends Genet 13:405-409.

Garrett KP, Haque D, Conaway RC, and Conaway JW (1994). A human cDNA encoding the small subunit of RNA polymerase II transcription factor SIII. Gene 150:413-414.

Hedrick SM, Cohen DI, Nielsen EA, and Davis MM (1984). Isolation of CDNA clones encoding T cell-specific membraneassociated proteins. Nature 308:149-153.

Helenius MA, Saramäki OR, Linja MJ, Tammela TLJ, and Visakorpi T (2001). Amplification of urokinase gene in prostate cancer. Cancer Res 61:5340-5344.

Hollas, W, Hoosein N, Chung LWK, Mazar A, Henkin J, Kariko K, Barnathan ES, and Boyd D (1992). Expression of urokinase and its receptor in invasive and non-invasive prostate cancer cell lines. Thromb Haemost 68:662-666.

Hubank M and Schatz DG (1994). Identifying differences in mRNA expression by representational difference analysis of cDNA. Nucleic Acids Res 22:5640-5648.

Jenkins RB, Qian J, Lieber MM, and Bostwick DG (1997). Detection of c-myc oncogene amplification and chromosomal anomalies in metastatic prostatic carcinoma by fluorescence in situ hybridization. Cancer Res 57:524-531.

Kallioniemi A, Kallioniemi OP, Sudar D, Rutovitz D, Gray JW, Waldman F, and Pinkel D (1992). Comparative genomic hybridization for molecular cytogenetic analysis of solid tumors. Science 258:818-821.

Kibel A, Iliopoulos O, DeCaprio JA, and Kaelin WG Jr (1995). Binding of the von Hippel-Lindau tumor suppressor protein to Elongin B and C. Science 269:1444-1446.

Kondo K and Kaelin WG Jr (2001). The von-Hippel Lindau tumor suppressor gene. Exp Cell Res 264:117-125.

Kononen J, Bubendorf $L$, Kallioniemi A, Bärlund M, Schraml $\mathrm{P}$, Leighton S, Torhorst J, Mihatsch MJ, Sauter G, and Kallioniemi OP (1998). Tissue microarrays for highthroughput molecular profiling of tumor specimens. Nat Med $7: 844-847$.

Krumm A and Groudine M (1995). Tumor suppression and transcription elongation: the dire consequences of changing partners. Science 269:1400-1401.

Liang $P$ and Pardee AB (1992). Differential display of eukaryotic messenger RNA by means of the polymerase chain reaction. Science 257:967-971.

Linehan WM and Klausner RD (1997). Renal carcinoma. In: Vogelstein B and Kinzler KW, editors. The genetic basis of human cancer. New York: McGraw-Hill, 455-473.

Linja MJ, Savinainen KJ, Saramäki OR, Tammela TLJ, Vessella RL, and Visakorpi T (2001). Amplification and overexpression of androgen receptor gene in hormone-refractory prostate cancer. Cancer Res 61:3550-3555.

Lisitsyn N, Lisitsyn N, and Wigler M (1993). Cloning the differences between two complex genomes. Science 259: 946-951. 
Magee JA, Araki T, Patil S, Ehrig T, True L, Humphrey PA, Catalona WJ, Watson MA, and Milbrandt J (2001). Expression profiling reveals hepsin overexpression in prostate cancer. Cancer Res 61:5692-5696.

Monni O, Bärlund M, Mousses S, Kononen J, Sauter G, Heiskanen M, Paavola P, Avela K, Chen Y, Bittner ML, and Kallioniemi A (2001). Comprehensive copy number and gene expression profiling of the 17q23 amplicon in human breast cancer. Proc Natl Acad Sci USA 98:5711-5716.

Nupponen N, Hyytinen E, Kallioniemi A, and Visakorpi T (1998a). Genetic alterations in prostate cancer cell lines detected by comparative genomic hybridization. Cancer Genet Cytogenet 101:53-57.

Nupponen NN, Isola J, and Visakorpi T (2000). Mapping the amplification of EIF3S3 in breast and prostate cancer. Genes Chromosomes Cancer 28:203-210.

Nupponen NN, Kakkola L, Koivisto P, and Visakorpi T (1998b). Genetic alterations in hormone-refractory recurrent prostate carcinomas. Am J Pathol 153:141-148.

Nupponen NN, Porkka K, Kakkola L, Tanner M, Persson K, Borg Å, Isola J, and Visakorpi T (1999). Amplification and overexpression of p40 subunit of eukaryotic translation initiation factor 3 in breast and prostate cancer. Am J Pathol 154:1777-1783.

Pan Y, Lui W-O, Nupponen N, Larsson C, Isola J, Visakorpi T, Bergerheim USR, and Kytölä S (2001). 5q11, 8p11, and 10 q22 are recurrent chromosomal breakpoints in prostate cancer cell lines. Genes Chromosomes Cancer 30:187-195.

Reiter RE, Gu Z, Watabe T, Thomas G, Szigeti K, Davis E, Wahl M, Nisitani S, Yamashiro J, Le Beau MM, Loda M, and Witte ON (1998). Prostate stem cell antigen: A cell surface marker overexpressed in prostate cancer. Proc Natl Acad Sci USA 95:1735-1740.
Saramäki O, Willi N, Bratt O, Gasser TC, Koivisto P, Nupponen NN, Bubendorf L, and Visakorpi T (2001). Amplification of EIF3S3 gene is associated with advanced stage in prostate cancer. Am J Pathol 159:2089-2094.

Schena M, Shalon D, Davis RW, and Brown PO (1995). Quantitative monitoring of gene expression patterns with a complementary DNA microarray. Science 270:467-470.

Tirkkonen M, Tanner M, Karhu R, Kallioniemi A, Isola J, and Kallioniemi OP (1998). Molecular cytogenetics of primary breast cancer by CGH. Genes Chromosomes Cancer 21: 177-184.

Velculescu VE, Zhang, L, Vogelstain B, and Kinzler KW (1995). Serial analysis of gene expression. Science 270:484487.

Visakorpi T, Kallioniemi A, Syvänen A-C, Hyytinen E, Karhu R, Tammela T, Isola J, and Kallioniemi O-P (1995). Genetic changes in primary and recurrent prostate cancer by comparative genomic hybridization. Cancer Res 55:342347.

Welsh JB, Sapinoso LM, Su AI, Kern SG, Wang-Rodriguez J, Moskaluk CA, Frierson HF Jr, and Hampton GM (2001). Analysis of gene expression identifies candidate markers and pharmacological targets in prostate cancer. Cancer Res 61:5974-5978.

Wittwer CT, Ririe KM, Andrew RV, David DA, Gundry RA, and Balis UJ (1997). The Light cycler $^{\mathrm{TM}}$ : A microvolume multisample fluorometer with rapid temperature control. Biotechniques 22:176-181.

Xu J, Stolk JA, Zhang X, Silva SJ, Houghton RL, Matsumura M, Vedvick TS, Leslie KB, Badaro R, and Reed SG (2000). Identification of differentially expressed genes in human prostate cancer using subtraction and microarray. Cancer Res 60:1677-1682.
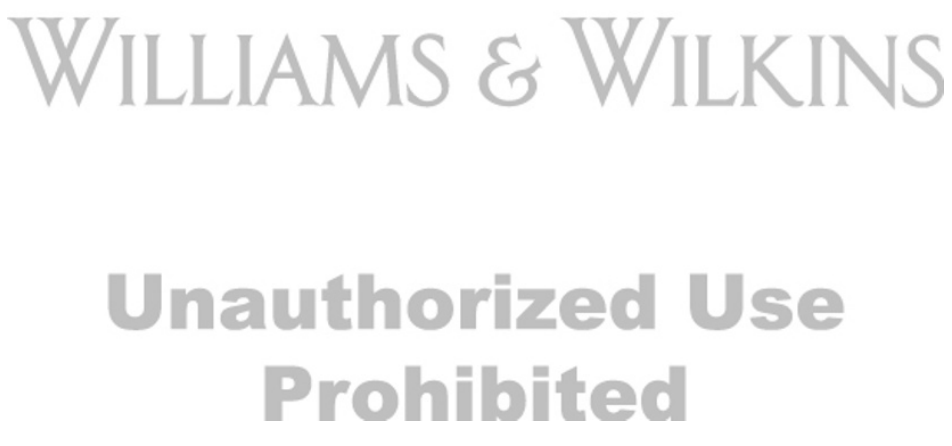